\title{
Maternal Mortality Risk Factors in Dr. Hasan Sadikin General Hospital, Bandung in 2009-2013
}

\author{
Shely Karma Astuti, ${ }^{1}$ Muhammad Alamsyah Aziz, ${ }^{2}$ Insi Farisa Desy Arya ${ }^{3}$ \\ ${ }^{1}$ Faculty of Medicine, Universitas Padjadjaran \\ ${ }^{2}$ Department of Obstetrics and Gynecology, Faculty of Medicine, Universitas Padjadjaran-Dr. Hasan Sadikin \\ General Hospital, Bandung \\ ${ }^{3}$ Department of Public Health, Faculty of Medicine, Universitas Padjadjaran
}

\begin{tabular}{|c|c|}
\hline Abstract & $\begin{array}{l}\text { Objective: To discover the factors affecting the occurrence of maternal } \\
\text { deaths. The high maternal mortality rate (MMR) in Indonesia is still a common } \\
\text { problem which needs urgent solution. }\end{array}$ \\
\hline & $\begin{array}{l}\text { Methods: This is an analytic observational, cross-sectional study using a case } \\
\text { control approach Fifty two cases were selected as cases, another } 52 \text { were } \\
\text { selected as control. The sampling was performed by simple random sampling. } \\
\text { The instruments used in this study were the medical records of mothers who } \\
\text { gave birth in Dr. Hasan Sadikin General Hospital Bandung from } 1 \text { January } \\
2009-31 \text { December } 2013 \text {. Data analysis was performed using chi-square test. }\end{array}$ \\
\hline & $\begin{array}{l}\text { Results: In this study, the results showed that the risk factors contributing } \\
\text { to maternal deaths were pregnancy complication }(p<0.001) \text {, delivery } \\
\text { complication }(p<0.001) \text {, puerpural complication }(p=0.022) \text {, age }(p=0.030) \text {, } \\
\text { parity }(p=0.427) \text {, prior medical history }(p<0.001) \text {, antenatal care }(p=0.007) \text {, } \\
\text { maternal education }(p=0.527) \text {, and area of residence }(p=0.049) \text {. }\end{array}$ \\
\hline $\begin{array}{l}\text { Received: } \\
\text { January 10, } 2017\end{array}$ & $\begin{array}{l}\text { Conclusions: The risk factors that contribute to maternal deaths include } \\
\text { pregnancy complication, delivery complication, puerpural complication, }\end{array}$ \\
\hline Revised: & history, antenatal care, and area of residence. \\
\hline & Keywords: Complication, maternal deaths, risk factors \\
\hline $\begin{array}{l}\text { Accepted: } \\
\text { August } 24,2017\end{array}$ & $\begin{array}{l}\text { pISSN: 2302-1381; eISSN: 2338-4506; http://doi.org/10.15850/ijihs.v5n2.992 } \\
\text { IJIHS. 2017;5(2):52-6 }\end{array}$ \\
\hline
\end{tabular}

\section{Introduction}

Maternal mortality rate (MMR) is an important component of the Human Development Index (HDI), a measure of a nation's development. ${ }^{1}$ Indonesia is one of the Southeast Asian countryies that have failed to reach the target of lowering MMR. In 2012, MMR in Indonesia was 359 per 100,000 live births, increasing increased from the rate in 2007 (228 deaths per 100,000 live births). ${ }^{2}$ The definition of maternal death according to the Tenth Revision of The International Classification of Diseases (ICD-10) is "the death of a woman while pregnant or within 42 days of termination of pregnancy, irrespective of the duration

Correspondence:

Shely Karma Astuti, Faculty of Medicine, Universitas

Padjadjaran

Jl. Raya Bandung-Sumedang KM 21 Jatinangor,

Indonesia

e-mail: shelykarma@gmail.com and site of the pregnancy, from any cause related to or aggravated by the pregnancy or its management but not from accidental or incidental causes". ${ }^{3}$

According to McCarthy and Maine, there are 3 determinant factors affecting maternal death. These three factors are divided into close, intermediate, and distant determinants. Close determinants include the immediate processes after maternal death such as complications in pregnancy, childbirth, or postnatal periods. Intermediate determinants are those which influence close determinants such as maternal health, reproductive status, access to health care, health care behavior or utilization of health care, and other unknown or unexpected factors. Distant determinants are those which influence the intermediate determinants such as sociocultural and economic factors. ${ }^{4}$ This study aimed to discover factors affecting the occurrence of maternal deaths. 


\section{Methods}

This study was an analytic observational, casecontrol study conducted in Dr. Hasan Sadikin General Hospital Bandung. Data were collected from the medical records of women giving birth in Dr. Hasan Sadikin General Hospital during the period from 1 January 2009-31 December 2013. This study had been approved by Health Research Ethics Committee Dr. Hasan Sadikin General Hospital, Bandung. The minimum sample size was calculated using the unpaired analytic comparative study formula which set 52 case subjects and 52 control subjects. The inclusion criterion in this study was medical records that include variables collected in this study. Medical records with incomplete or missing data were excluded.

Out of 104 maternal death cases identified, 52 fulfilled the inclusion criterion. Samples were selected using simple random sampling method and were assigned into the case group.

Table 1 Characteristics of Case and Control

\begin{tabular}{|c|c|c|c|}
\hline \multirow{2}{*}{ Risk Factors } & \multicolumn{2}{|c|}{ Result (n=52) } & \multirow{2}{*}{ p Value } \\
\hline & Death (\%) & Death (\%) & \\
\hline \multicolumn{4}{|l|}{ Pregnancy complication } \\
\hline Yes & $21(40 \%)$ & $5(9 \%)$ & \multirow{2}{*}{$<0.001$} \\
\hline No & $31(60 \%)$ & 47 (90\%) & \\
\hline \multicolumn{4}{|l|}{ Delivery complications } \\
\hline Yes & $41(79 \%)$ & $22(42 \%)$ & \multirow{2}{*}{$<0.001$} \\
\hline No & $11(21 \%)$ & $30(58 \%)$ & \\
\hline \multicolumn{4}{|l|}{ Puerpural complications } \\
\hline Yes & $11(21 \%)$ & $3(6 \%)$ & \multirow{2}{*}{0.022} \\
\hline No & $41(79 \%)$ & $49(94 \%)$ & \\
\hline \multicolumn{4}{|l|}{ Maternal age } \\
\hline$<20$ years or $>35$ years & $20(38 \%)$ & $10(19 \%)$ & \multirow{2}{*}{0.030} \\
\hline 20-35 years & $32(61 \%)$ & $42(81 \%)$ & \\
\hline \multicolumn{4}{|l|}{ Parity } \\
\hline$<1$ or $>4$ & $24(46 \%)$ & $20(38 \%)$ & \multirow{2}{*}{0.427} \\
\hline $1-4$ & $28(53 \%)$ & $32(61 \%)$ & \\
\hline \multicolumn{4}{|l|}{ Prior medical history } \\
\hline Yes & $23(44 \%)$ & $2(4 \%)$ & \multirow{2}{*}{$<0.001$} \\
\hline No & $29(56 \%)$ & $50(96 \%)$ & \\
\hline \multicolumn{4}{|l|}{ Antenatal care } \\
\hline$<4$ times & $13(25 \%)$ & $3(6 \%)$ & \multirow{2}{*}{0.007} \\
\hline$\geq 4$ times & $39(75 \%)$ & $49(94 \%)$ & \\
\hline \multicolumn{4}{|l|}{ Maternal education } \\
\hline$<9$ years & $37(71 \%)$ & $34(65 \%)$ & \multirow{2}{*}{0.527} \\
\hline$\geq 9$ years & $15(29 \%)$ & $18(34 \%)$ & \\
\hline \multicolumn{4}{|l|}{ Area of residence } \\
\hline Urban & $28(63 \%)$ & $23(44 \%)$ & \multirow{2}{*}{0.049} \\
\hline Rural & $24(36 \%)$ & $29(56 \%)$ & \\
\hline
\end{tabular}


Data collection was done on the control group which also had 52 subjects (case-control ratio $=1: 1$ ). After data collection, data tabulated using Microsoft Excel, and bivariate analysis was performed using chi-square test through the use of statistics software.

Complications in pregnancy, delivery, and the puerpural period were analyzed. Analysis was also performed on maternal age, parity, maternal medical history, antenatal care, maternal education, and area of residence.

\section{Results}

The number of maternal patients giving birth in Dr. Hasan Sadikin General Hospital from 2009 to 2013 was 13,453 people, with 104 $(0.77 \%)$ death cases.

Both groups characteristics (case and control) presented in Table 1 show correlations were found between pregnancy complication $(p<0.001)$, delivery complication $(p<0.001)$, puerpural complication $(\mathrm{p}<0.022)$, maternal age $(p<0.001)$, antenatal care $(p=0.007)$, and area of residence $(p=0.049)$ and the incidence of maternal deaths. Meanwhile, parity and education variables did not show significant correlations to maternal deaths $(\mathrm{p}>0.05)$.

OR analysis with $95 \%$ confidence interval (CI) was performed to measure the effects of significant variables on the incidence of maternal deaths (Table 2).

\section{Discussion}

This was a case-control study involving 104 samples comprising of 52 cases and 52 controls. Maternal death risk factors were classified into three determinants: close, intermediate, and distant. ${ }^{4}$ The study variables included as close determinants were complications during pregnancy, complications during birth, and also neonatal complications. All close determinants included in this study had a significant correlation with the incidence of maternal deaths (Table 1). Mothers with complications during pregnancy had a 6.368 times larger risk to suffer maternal death compared to those without them. Mothers with complications during birth were 5.083 times more vulnerable to maternal deaths compared to those without them. Mothers with neonatal complications had a maternal death risk that was 4.382 times larger than those without them. This findings supported previous studies which discover that obstetric complications, i.e. pregnancy complications, delivery complications, as well as puerpural complications, are risk factors for maternal deaths. ${ }^{4,5}$ Obstetric complications that directly result in maternal deaths contribute to $75 \%$ of all maternal deaths. Such deaths can actually be prevented through medical interventions. ${ }^{6}$

Age, prior medical history, and antenatal care, which are intermediate determinants, showed significant results (Table 1). Mother who were under 20 or over 35 had 2.625 times larger risk than mothers age 20-35. Age that is too young or too old had an effect on the condition of the uterus. Mothers that are too young are not physically ready yet to conceive and give birth. ${ }^{7,8}$ Comparing the two highrisk age groups, more maternal deaths came from the young age mothers. ${ }^{8}$ Mothers with a history of diseases had 19.828 times larger risk compared to those without any history. Prior medical history included diseases that had been suffered by the mothers before

Table 2 Maternal Death Risk Factors

\begin{tabular}{lccc}
\hline \multicolumn{1}{c}{ Risk Factors } & \multicolumn{3}{c}{ Results } \\
\cline { 2 - 4 } & p Value & OR & $\mathbf{9 5 \%}$ CI \\
\hline Pregnancy complication & $<0.001$ & 6.368 & $2.172-18.668$ \\
Delivery complication & $<0.001$ & 5.083 & $2.143-12.053$ \\
Puerpural complication & 0.022 & 4.382 & $1.145-4.382$ \\
Maternal age & 0.030 & 2.625 & $1.081-6.377$ \\
Prior medical history & $<0.001$ & 19.828 & $4.356-90.258$ \\
Antenatal care & 0.007 & 5.444 & $1.449-20.462$ \\
Area of residence & 0.049 & 2.190 & $0.998-48.07$ \\
\hline
\end{tabular}


conceiving/giving birth and would give the pregnancy an effect or greater burden. Mothers with poor antenatal care were more prone to maternal deaths by 5.444 times than those without it. Antenatal care functions to screen mother for other diseases or disorders that the mother has. In India (2013), 7 out of 10 mothers passed away because they did not receive antenatal care. Government's intervention in the form of family planning is needed to address this issue. ${ }^{9}$

In this study, the factor that was included as distant determinants was mother's area of residence. Mothers that stayed far from health care facility had a 2.190 times larger risk compared to those who stayed close to one (urban). This finding supported a previous study in Gambia. ${ }^{6}$ As the referral hospital in West Java, the cases handled in Dr. Hasan Sadikin General Hospital were all referred cases. The distant location is one of the 3 "too late" causes of maternal deaths. ${ }^{10}$ This was because patients needed more time to reach Dr. Hasan Sadikin General Hospital, causing them to arrive late and receive late treatments. ${ }^{6,11}$ For this reason, maternal deaths are 11 times more likely to happen in referral hospitals if the patients do not arrive in two hours. ${ }^{5}$

The problem of maternal deaths demands serious attention because it affects not only the mothers, but also their families. When its occur, other family members will have a decrease in their productivity which will

\section{References}

1. Helmizar. Evaluasi kebijakan jaminan persalinan dalam penurunan angka kematian ibu. KEMAS. 2014;9(2):197-205.

2. Prakarsa Welfare Initiative for Better Societies. Angka kematian ibu melonjak, Indonesia mundur 15 tahun. [cited 2013 Dec 6]. Available from: http://theprakarsa.org/new/in/papers/ detail/19/Angka-Kematian-Ibu-AKI-MelonjakIndonesia-Mundur-15-Tahun.

3. Shirin S, Nahar S. Maternal mortality-a public health problem. Ibrahim Med Coll J. 2012;6(2):64-9.

4. Khaskheli MS, Baloch S, Sheeba A. Risk factors and complications of puerperal sepsis at a tertiary healthcare centre. Pak J Med Sci. 2013;29(4):972-6.

5. Abi Bazar, Theodurus, Zaimursyaf Aziz, Azhari. Maternal mortality and contributing factors. INAJOG. 2012;36(1):8-13. eventually affect the family's economy and social status. ${ }^{12,13}$ Multi-sector governmental intervention is needed to solve this problem. ${ }^{11}$ Policies need to be made according to the principle of decentralization so as to achieve effectiveness and efficiency in each region. ${ }^{2}$

One of the limitations of this study was that the unsuitability of the definition of maternal death with the conditions in Dr. Hasan Sadikin General Hospital. Maternal deaths include the deaths that occur during pregnancy up to 42 days after birth; however, the medical records only had information about pregnancy up to a few days of hospital care. There was no data of maternal condition up to the $42^{\text {nd }}$ day after birth. Besides that, another limitation was the limited number of samples.

The number of missing medical records was not a little. Complete medical records and systematic, careful filing of medical records should be done. If possible, they can be done through a computerized system to prevent missing or incomplete data and expedite data searching. Further studies should apply different method so that other factors that affect maternal deaths can also be observed.

Hence, it is concluded that the risk factors that affect maternal deaths in Dr. Hasan Sadikin General Hospital from 2009 to 2013 comprise of pregnancy, delivery, and puerpural complications, maternal age, prior medical history, antenatal care, and area of residence.

6. Cham M, Sundby J, Vangen S. Maternal mortality in the rural Gambia, a qualitative study on access to emergency obstetric care. Reproductive Health. 2005;2(3):1-8.

7. Suwal JV. Maternal mortality in Nepal: unraveling the complexity. Canadian Studies in Population. 2008;35(I):1-26.

8. Datta D, Datta PP. Maternal mortality in India: problems and challenges. Asian J Med Res. 2013;2(1):33-5.

9. Nove A, Matthews Z, Neal S, Camacho AV. Maternal mortality in adolescents compared with women of other ages: evidence from 144 countries. The Lancet Global Health. 2014;2(3):e155-64.

10. Nour NM. An introduction to maternal mortality. Rev Obstet Gynecol. 2008;1(2):77-81.

11. Khan N, Pradhan MR. Identifying factors associated with maternal deaths in Jharkhand, 
India: a verbal autopsy study. J Health Popul Nutr. 2013;31(2):262-71.

12. Hernandez JC, Moser CM. Community level risk factors for maternal mortality in Madagascar. Afr Reprod Health. 2013;17(4):118-29.

13. Gurnadi JI, Mose JC, Handono B, Fauziah PN,
Pramatirta AY. Correlation between fms-Like tyrosine kinase-1 (sFlt-1) cell-free messenger RNA expression and fms-Like tyrosine kinase-1 (sFlt-1) protein level in severe preeclampsia and normal pregnancy. IJIHS. 2015;3(2):66-71. 